\title{
Entrecruzamentos de Imagens e Sons: de Bonecos a Humanos, do Teatro Bunraku ao filme Dolls
}

\section{Criss-cossing Images and Sounds: from dolls to humans, from Bunraku Theatre to the film Dolls}

Maria Helena Braga e Vaz Costa ${ }^{1}$ Gustavo Henrique Lima Ferreira ${ }^{2}$ 


\section{Resumo}

Este texto propõe uma análise das relações existentes entre o Teatro Bunraku e o filme Dolls (2002) do diretor japonês Takeshi Kitano. A intenção aqui é considerar o diálogo do filme Dolls com o teatro Bunraku, aprofundando a questão da construção fílmica como espaço de diálogo entre elementos da linguagem teatral e da linguagem cinematográfica. Isto é considerado a partir da maneira como o Takeshi Kitano constrói o espaço fílmico.

Palavras-chave: Teatro Bunraku; Filme Dolls; Takeshi Kitano; Linguagem

\section{Abstract}

This article analyses the existing relationship between the Bunraku Theatre and the film Dolls (2002) by the japonese filmmaker Takeshi Kitano. The aim is to consider the dialogue between the film Dolls with the Bunraku, questioning the film construction as a dialogue space between the theatrical and the cinematic language. This is considered from the ways in which the filmmaker Takeshi Kitano builds narrative filmic space.

Keywords: Bunraku Theatre; Film Dolls; Takeshi Kitano; Language

\footnotetext{
${ }^{1}$ Profa. Dra. Associada - Departamento de Artes, da Universidade Federal do Rio Grande do Norte (UFRN). Professora permanente do Programa de Pós-Graduação em Estudos da Mídia (PPGEM) e do Programa de Pós-Graduação em Geografia (PGE) da UFRN. Bolsista de Produtividade em Pesquisa do CNPq. mhcosta@ufrnet.br

${ }^{2}$ Mestre. Professor Assistente - Curso de Licenciatura em Teatro, Universidade Federal do Tocantins (UFT). gushlf@gmail.com
} 
De bonecos a humanos - A relação que será discutida nesse artigo, entre o filme Dolls (2002) e o teatro Bunraku, não se pauta por uma cópia, ou mesmo por um transporte direto desse teatro para a tela do cinema. O que Kitano propõe em Dolls é uma troca, um diálogo entre as questões do Bunraku com questões do seu próprio cinema. Dentro dessa análise, é importante observar a relação entre a pequena cena inicial, onde é apresentado um fragmento de um espetáculo do Bunraku, e o restante do filme, inclusive chamando atenção para as diferenças de tratamento entre esses dois momentos. Como Cassio Abe vai destacar, Kitano usa diferentes técnicas para esse primeiro momento.

Em primeiro lugar, podemos mencionar a introdução agressiva de um trabalho de filmagem "cinético", que se baseia nas possibilidades técnicas da câmera (sua habilidade de mover, dar zoom e assim por diante). A filmagem no começo do filme, que captura uma apresentação do drama de Bunraku de Monzaemon Chikamatsu, Mensageiro do Inferno (Meido no hikyaku), é particularmente anti-Kitano. A câmera, que circula muito próxima em torno dos bonecos, deixa que os gestos conferidos pelos manipuladores, vestidos de preto, sejam vistos alternadamente de forma parcial e total. A técnica aqui nega a unidade do próprio plano e, contudo, uma certa "tenacidade" difícil de agarrar aparece na filmagem. (Abe, 2005, p. 253) (Tradução nossa). ${ }^{3}$

Não é à toa que o diretor vai lançar mão dessa forma, anti-Kitano segundo Abe, exclusivamente para a cena inicial do teatro Bunraku, corroborando com a noção de não se tratar aqui da simples e direta transposição desse teatro. A câmera corre, se aproxima e se distancia, quebrando com a noção de "teatro filmado" que poderia ser causada em uma filmagem estática e de plano aberto. Esse tipo de plano também poderia criar uma falsa sensação de unidade, contraditória a ideia do sangyo, dessa tríade do Bunraku, onde narração, música e manipulação se apresentam separadas, num processo que privilegia uma construção simultânea e harmoniosa, ao invés de uma unidade planificada.

Os cortes, movimentos e planos de câmera, procuram manter essa simultaneidade da cena do Bunraku no filme e, para isso, "planos de todo o palco, do narrador e da audiência também são inseridos de forma complexa". (Abe, 2005, p. 253)(Tradução nossa) ${ }^{4}$. Essa construção fílmica também vai destacar o drama do casal de bonecos, com fortes closes e recortes da câmera, que, em diversos momentos, apagam da tela as figuras dos manipuladores, consequentemente, humanizando esses bonecos, dando-lhes vida própria, até que em seguida, eles ganhem total independência, quando apresentados sozinhos em um fundo preto.

\footnotetext{
${ }^{3}$ First of all, we could mention the aggressive introduction of "kinetic" camerawork, which relies on the camera's technical possibilities (its ability to travel, zoom, and so forth). The camerawork at the opening of the film, which captures a performance of Monzaemon Chikamatsu's bunraku puppet drama, The Courier of Hell (Meido no hikyaku), is particularly anti-Kitano. The camera, which circles around quite close to the puppets, alternately resents total and partial view of the gestures being bestowed by the black-robed puppeteers. The technique here denies the unity of the shot itself, and yet a certain difficult-to-grasp "tenacity" appears in the camerawork (Abe, 2005, p. 253).

${ }^{4}$ Shots of the entire stage, the narrator, and the audience are also inserted in a complex manner. (Abe, 2005, p. 253)
} 


\section{Sequência 1}
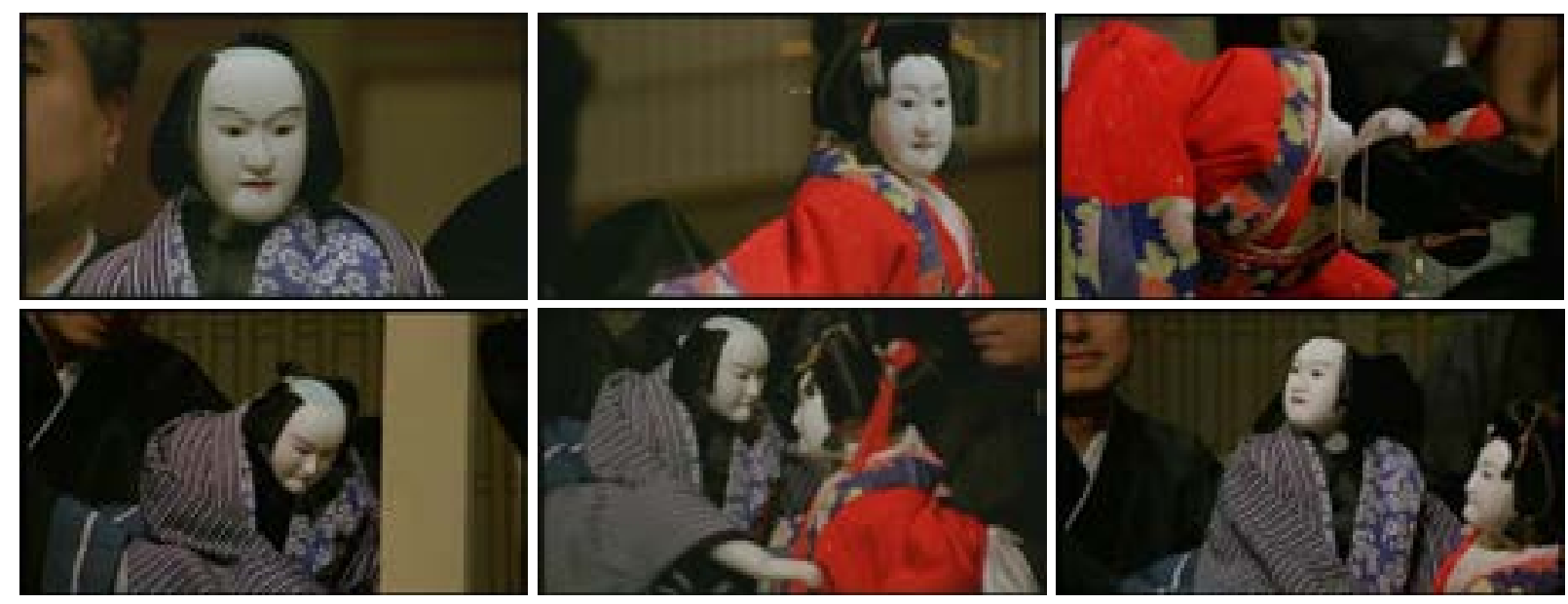

Exemplos de closes da câmera nos personagens de Chubei e Umegawa. Dolls (2002).

Então, assim que o casal principal da peça de marionetes se aproxima do seu trágico duplo suicídio e começa a olhar para o "mundo humano" de uma nova perspectiva, o sujeito dessa filmagem "cinética" se transfere da esfera das marionetes para o mundo dos humanos. Planos como o abrupto e agressivo frontal reverso, familiar aos filmes anteriores de Kitano são adicionados. Isto reforça a incongruência intencionalmente criada no roteiro. (Abe, 2005, p. 254 - tradução Gustavo Henrique). ${ }^{5}$

A cena apresenta então o revés desse quadro, quando o casal de mendigos acorrentados aparece na tela como dois bonecos vagando pelo espaço, sustentados um pelo outro por essa corda que os une. Nesse momento, o excesso de cortes, movimentos, closes, vistos na cena inicial de Bunraku vai dar lugar a planos longos, contínuos e abertos que vão ser trabalhados ao longo das três histórias, no "mundo dos humanos". A incongruência a qual Abe se refere nesse momento, está na passagem da cena das marionetes para os humanos, na ligação entre esses dois momentos, que apresentam formas de realização, no que se refere ao uso das técnicas de filmagem, completamente distintas. Essa aparente incongruência, vai servir à construção dramática que Kitano pretende apresentar entre esses dois mundos, o das marionetes e o dos humanos. Ao fim da cena inicial, portanto, esses bonecos que se desvencilham de seus manipuladores, tornam-se os próprios contadores e condutores dessa história que começa. A história desses casais de humanos que se tornam manipulados.

A forma como é feita essa transposição, da cena dos bonecos para os atores humanos, tem como base a relação traçada pelo olhar das marionetes. $O$ casal de bonecos, Chubei e Umegawa, aparece liberto da presença dos manipuladores. Eles se olham e depois se viram na direção da câmera, não olhando diretamente, mas para além da tela, se colocando como observadores dessa história que vai ser contada diante delas. Já em primeiro plano, fica claro que as marionetes se reconhecem naquela história, mas faz com que o olhar do espectador seja mediado pelo casal

\footnotetext{
${ }^{5}$ Then, just as the leading couple in the puppet play approaches their tragic double suicide and begin to look at the "human world" from a new perspective, the subject of this "kinetic" camerawork shifts from the realm of puppets to the world of humans. Shots such as the abrupt and aggressively frontal reverse shots familiar from Kitano's previous films are added in. This reinforces the sense of incongruity that is intentionally created in the shooting script. (Abe, 2005, p. 254).
} 
de bonecos. O espectador observa aquelas histórias através do olhar de Chubei e Umegawa. O olhar, portanto, parte do espectador para as marionetes, delas para os personagens do filme. Ao olharem para além da câmera, o casal de marionetes olha também para o espectador em si. Esse olhar, portanto, coloca o próprio espectador em relação aos personagens dessas três histórias, que estão pra ser contadas. Toda a mediação dessa relação é então feita por Chubei e Umegawa, no papel de contadores das histórias ${ }^{6}$.

Dolls poderia ser visto como 'marionetes humanas' interpretando uma história concebida por bonecos do Bunraku. O filme começa durante sua hora de trabalho, sua performance. E depois que o dia de trabalho acaba, eles descansam sozinhos e começam a contar suas histórias. (Kitano, 2002 - tradução Gustavo Henrique). ${ }^{7}$

\section{Sequência 2}
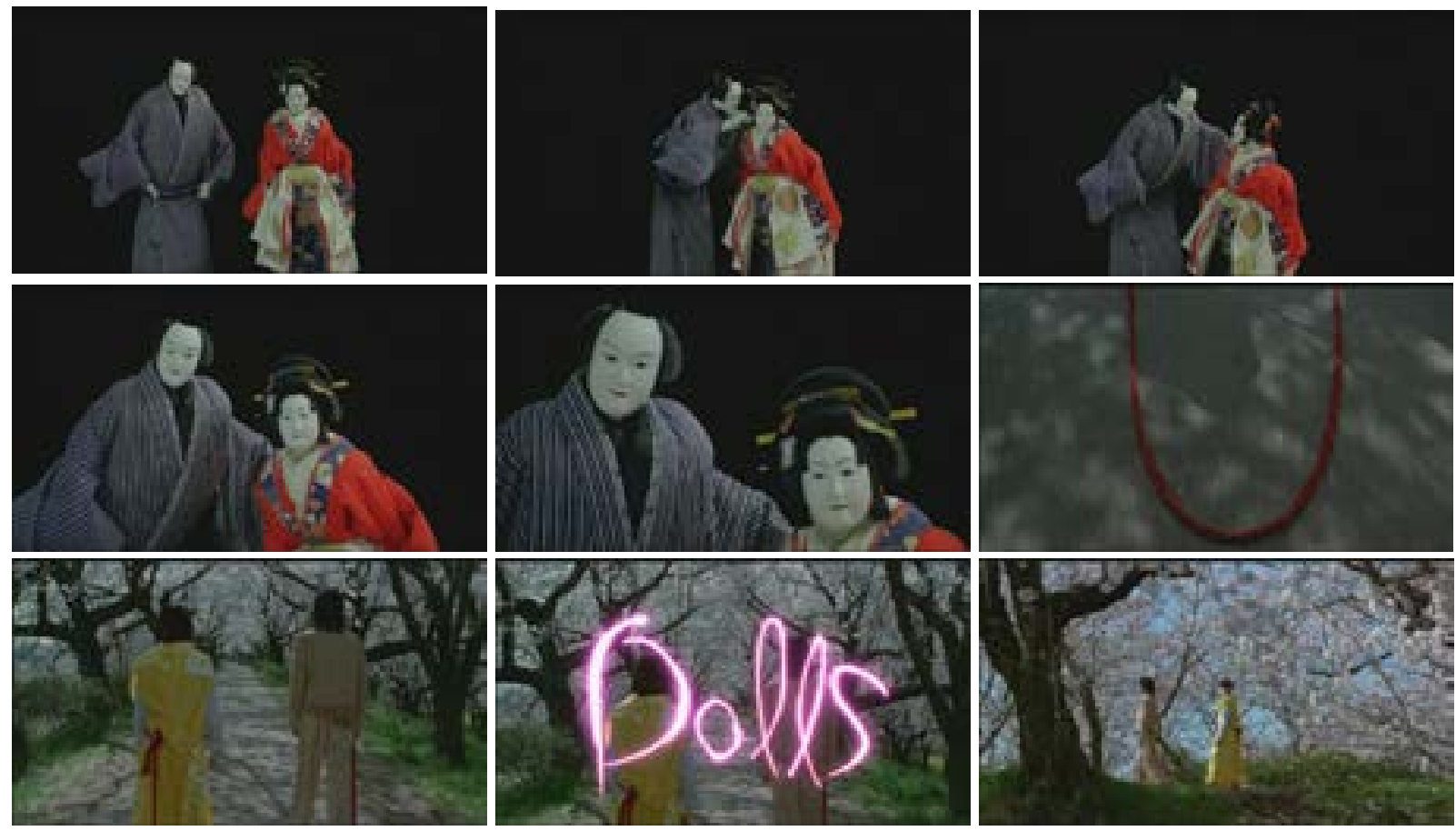

Destaque para a relação estabelecida pelos bonecos, Chubei e Umegawa, que direcionam o olhar para o casal de "marionetes humanas", Matsumoto e Sawako. Esse primeiro momento então, com a apresentação do espetáculo Meido no Hikyaku, se apresenta como início do filme, mas não como início da diegese. Define quem serão os contadores, no caso o casal de bonecos, e, portanto, estaria próximo de um prefácio, de uma introdução a esse universo de diálogo com o teatro Bunraku.

Um ponto importante nessa relação estabelecida, pelo olhar do casal de bonecos para com o casal de humanos, está no fato dela partir exatamente da imagem da corda que une Matsumoto e Sawako. A corda funciona como um elemento simbólico

\footnotetext{
${ }^{6}$ Essa lógica vai ser reforçada no final do filme, quando, assim que a história é encerrada, Chubei e Umegawa aparecem novamente em uma repetição desse processo, retomando o olhar para aquela história que se encerrou e reafirmando a posição de contadores e mediadores dela.

${ }^{7}$ DOLLS could be seen as 'human puppets' playing out a story conceived by Bunraku dolls. The film starts during their working hours, their performance. And after their day's work is done, they rest alone and start telling stories (Kitano, 2002).
} 
da transformação desse casal em duas marionetes, "nos mendigos acorrentados". A cor é fundamental, já que no Bunraku, o vermelho, cor do sangue e cor do sol na bandeira japonesa, vai representar a força da vida. A corda vermelha, portanto, aparece não apenas com um simples material que as une, mas como esse último fio de vida, como esse laço que os sustenta ao longo de toda a caminhada. A esse respeito, é importante ressaltar que a cor no cinema, como ressalta Maria Helena Braga e Vaz da Costa, apresenta valores específicos e possibilita o estímulo de reações e sensações ao espectador: "seus significados simbólicos e psicológicos podem consequentemente ser explorados pelos cineastas com o intuito de obter uma faixa completa de efeitos de significação" (Costa, 2011, p. 118).

As cores vão aparecer em Dolls, de modo semelhante ao que ocorre no Bunraku, como elementos simbólicos de representação. Kitano usa toda uma palheta de cores que apresenta a caminhada desses casais ao longo das estações do ano e, que em cada estação, se desdobra em significados específicos e, muitas vezes sutis. Um dos "modos cinemáticos de explorar a cor, por exemplo, é escolher as cores de uma cena exterior de acordo com a estação do ano, a hora do dia, e as condições meteorológicas" (Costa, 2011, p. 118). O vermelho, por exemplo, que Costa defende como sendo uma cor de impressão forte, que atrai a atenção, vai aparecer tomando praticamente toda a tela na representação do outono, apresentando as folhas de cerejeira que caem sobre o campo, assim como o sangue que se espalha dos personagens que perdem suas vidas. Observa-se, então, a relação com o vermelho "força da vida", do teatro de bonecos, com a queda das folhas da cerejeira, que apresenta a queda dessas vidas.

Também nesse momento é importante destacar pela primeira vez um recurso que irá aparecer com frequência durante todo o processo da caminhada do casal. É o uso de um plano lateral de filmagem, com a câmera quase sempre parada, ou se movendo muito lentamente, mostrando os atores a percorrer todo o espaço da cena de um lado a outro da tela. Essa relação corresponde diretamente ao espaço da cena no teatro Bunraku, onde do ponto de vista do espectador os bonecos executam as ações explorando a horizontalidade do palco. 


\section{Sequência 3}
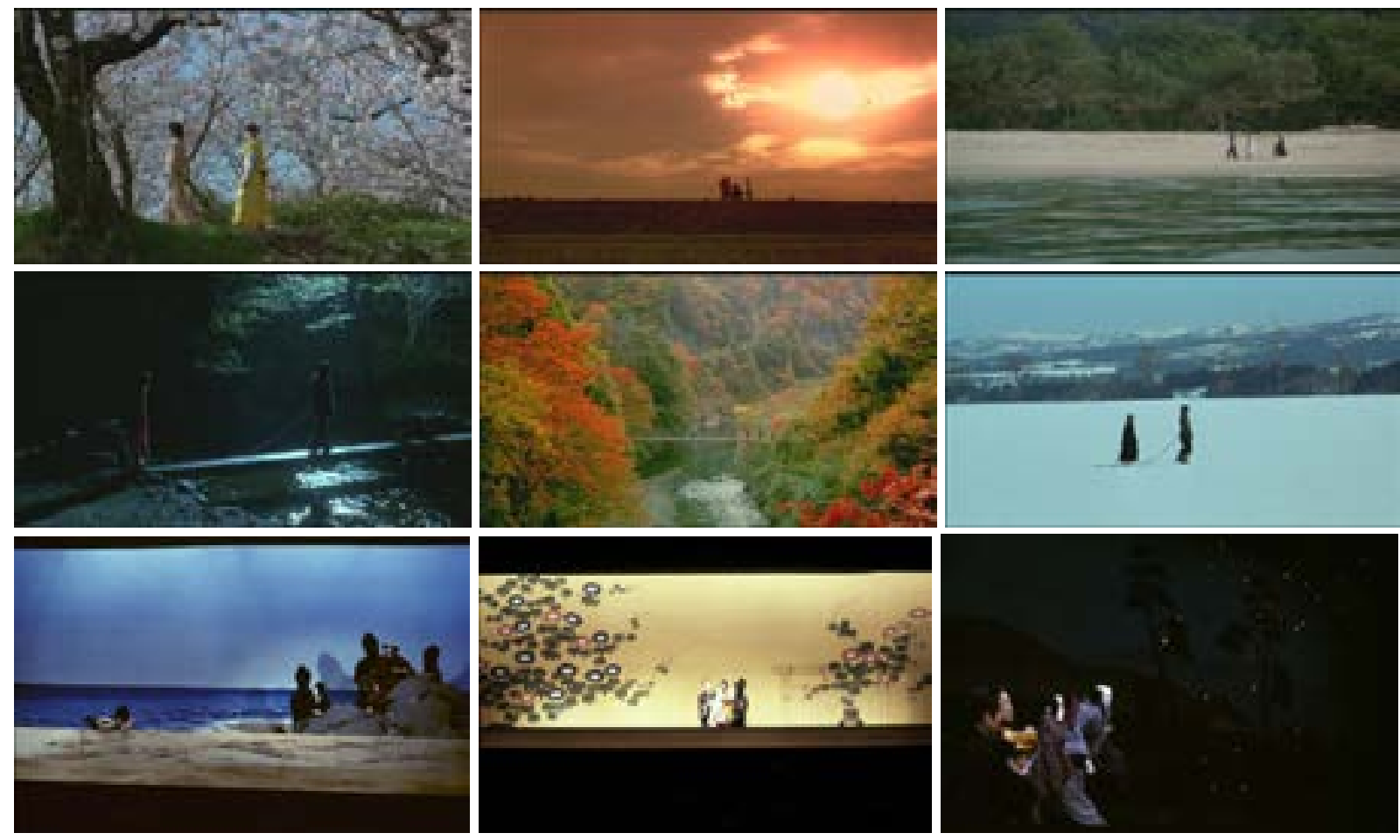

Courtesy of The Barbara Curtis Adachi Bunraku Collection, C.V. Starr East Asian library, Columbia University

Na primeira e segunda linhas observam-se diferentes momentos do filme Dolls (2002), onde é feito uso do plano lateral de filmagem, ressaltando a horizontalidade da cena, em comparação com imagens de espetáculos do teatro Bunraku, na terceira linha. Outra característica importante é que esses planos, em Dolls, são quase sempre muito abertos, apresentando lugares e cenários grandiosos, onde os personagens se mostram diminutos, como pequenos bonecos, presos a esse espaço que efetivamente tentam percorrer, reforçando essa relação com os bonecos do teatro Bunraku.

Retomando a cronologia da cena, nesse momento, o casal Matsumoto e Sawako é apresentado já caminhando como os "mendigos acorrentados", numa clara antecipação do que ainda está para ocorrer com os dois. No Bunraku o narrador revela e até mesmo antecipa, em diversos momentos, o que está para acontecer aos personagens, dentro da relação de simultaneidade das três artes. Foi visto também que, em Dolls, não existe uma figura explícita que narre a história, mas esse papel é assumido pela direção e, principalmente pela edição do filme, através da forma como as cenas se intercalam e se desenvolvem. Essa apresentação do filme, portanto, com os mendigos acorrentados caminhando, antes mesmo que tenhamos conhecimento de sua história apresenta um momento de deslocamento, antecipações fora do tempo corrente da narrativa, antecipando algo para o espectador. A história do casal não começa com os dois amarrados, mas sim na cena seguinte, na igreja, de onde se estabelece de fato o início da diegese do filme. Essa antecipação não transforma o momento da igreja num flashback, numa lembrança de algo passado, quando, pelo contrário, é a cena inicial do casal que se estabelece como uma espécie de flash-for ward, de adiantamento do que ainda está por vir.

É evidente que, dentro de uma análise técnica, toda essa relação poderia ser 
entendida sim como um flashback que segue a aparição inicial do casal. A intenção aqui, porém e de destacar como se estabelece a diegese do filme para o espectador e, nesse sentido, quando o casal aparece, ainda não há nenhuma relação estabelecida, nem entendimento algum do sentido de sua aparição. Eles ainda não foram identificados dentro da trama e, portanto, essa primeira aparição funciona como uma pequena mostra, como um teaser dos caminhos que a história ainda está para percorrer. É nesse sentido que se coloca aqui a noção de flash-forward, de adiantar para o espectador algo que só irá se concretizar em um momento futuro da trama.

A partir da igreja, portanto, que a trama começa a se desenvolver, quando surgem as informações da história desse casal, de que o casamento preparado para Matsumoto não é com sua noiva Sawako, mas sim com a filha de seu chefe. Aqui, mais um pequeno exemplo de adiantamento vai ocorrer, com a imagem dos amigos de Sawako que irrompe durante um plano sequência da entrada da igreja, antes da efetiva aparição dos mesmos, que informam a Matsumoto da tentativa de suicídio dela. O que chama a atenção nessa cena, porém, é que boa parte das informações são apresentadas evocando de uma sequência de flashbacks, o que também reforça a noção desse como o ponto inicial da trama, estabelecendo uma sequência na qual podem ser observados avanços e recuos, mas que sempre retomam o ponto deixado anteriormente conectando-se com o momento e, mesmo com o lugar espacial da cena. Essas cenas de flashback são em geral curtas e bastante específicas, como as lembranças da tentativa de suicídio de Sawako.

O filme parte de um ponto central, da cena do casamento, e, ao mesmo tempo em que a história se desenvolve linearmente, diversas pequenas inserções são feitas, revelando questões importantes e adiantando momentos que ainda estão por vir. Mais uma vez, essa estrutura narrativa apresentada no inicio do filme não traz nenhum recurso novo, mas aqui, conectada ao momento inicial, com o teatro de bonecos, essa apresentação da história a partir de diferentes planos da trama, lançando mão de flashbacks e flash-forwards, de adiantamentos e lembranças, deixa claro esse papel de narrador que Kitano procura exercer através da edição do filme. Assim como o narrador do Bunraku é responsável tanto pelas cenas e personagens, quanto pelas narrações e informações complementares, especialmente no momento inicial da peça, onde apresenta para o público aquela história e seus personagens, no filme a edição/direção vai, dentro da diegese, inserir esses pequenos momentos de informações complementares, esses flashbacks e flash-forwards que apresentam para o espectador questões fundamentais para a compreensão da história.

Chega-se então, ao que pode ser considerado como o começo dessa história, quando Matsumoto recebe a notícia da tentativa de suicídio de Sawako e corre para tentar resgatá-la. A ênfase aos vínculos de Matsumoto ganha força pois foi sua ação, ou melhor, sua não ação, ao abdicar da noiva aceitando um casamento armado, que desencadeou a atitude de Sawako.

A escolha entre o giri (os deveres a cumprir) e o ninjô (as vontades do indivíduo), fundamental dentro da construção dramática do Bunraku, se apresenta já nesse começo da trama. Matsumoto precisa escolher efetivamente entre seus deveres, representados pela filha de seu chefe a espera no altar, e seu vínculo pessoal com a mulher que ama. Quando Matsumoto resgata Sawako, ele passa a ser ligado também por um 
dever a ela, uma obrigação em cuidá-la. Essa relação se diferencia, porém, por ter sido gerada em ações e sentimentos individuais. A tentativa de suicídio de Sawako é um ato individualista, que leva Matsumoto a cometer outro, quando abandona o casamento. A partir daí fica claro todo um processo de isolamento e afastamento dos vínculos sociais que se impõe ao casal. Trabalho, amigos e familiares vão sendo deixados para trás, até que, a própria civilização fique para trás, quando o casal abandona a área urbana e segue para a floresta.

Matsumoto e Sawako deixam de pertencer ao convívio social e, pela primeira vez, aparecem amarrados, deixando clara essa nova relação de dever que os une, mas que, forjada pelas vontades individuais, os isola de todo o resto. A corda vermeIha inicialmente se apresenta fina e frágil, mas já em seguida o casal caminha pela floresta amarrado por uma grossa corda vermelha. Retoma-se o momento inicial, o flash-forward deixado no início, agora dentro da estrutura cronológica da diegese e encerrando o que poderia ser chamado de primeiro bloco dessa história do casal.

Esse momento, além de marcar o fim de um bloco dessa história, encera também um momento maior, um ciclo dentro da composição diegética do filme como um todo, que pode ser compreendido como a primavera. Estabelecendo uma relação com a noção do michiyuki, uma cena de caminhada que precisa obrigatoriamente ser incluída em todos os espetáculos do Bunraku, uma de suas questões fundamentais é a passagem do tempo e, com isso, das estações do ano. Em Dolls, essas estações são extremamente bem definidas e, mantendo a noção da caminhada, elas delineiam toda a construção e seguimento não apenas da primeira história, como das outras duas, definindo, inclusive, o momento de aparição dessas outras histórias, como será visto mais adiante.

\section{Sequência 4}
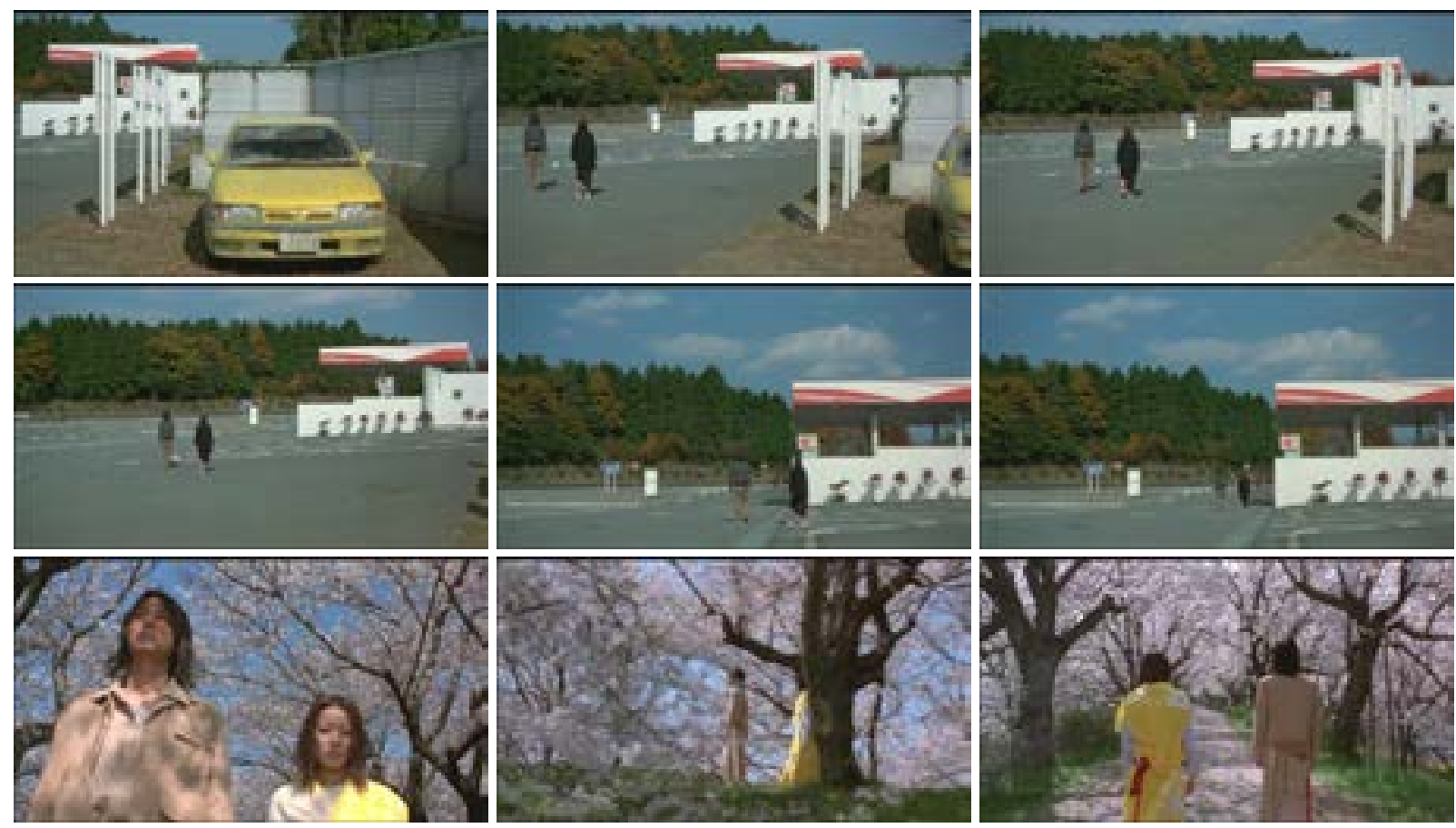

O casal, pela primeira vez como mendigos amarrados, segue em direção à floresta, retomando o momento inicial de abertura do filme 


\section{As estações}

As estações do ano desempenham um papel importante dentro da narrativa de Dolls. O filme é construído como essa grande "cena da caminhada", o michiyuki, que tanta importância tem dentro da estrutura cênica do Bunraku e essa passagem das estações apresentam os diferentes estágios de cada uma das três histórias e funcionam como elemento de ligação, não somente das histórias entre si, como de seus personagens com toda a estrutura estética e dramática que os cercam. Por esse motivo, será feita a seguir uma análise de cada uma dessas estações e de como elas se desenvolvem, ressaltando as características que as definem, assim como alguns de momentos significativos em cada uma delas.

Essa divisão pelas estações, busca criar uma unidade coesa, apresentando um momento desse caminho a ser percorrido. Para a construção dessa unidade, mais uma vez vai ser visto um diálogo com as convenções do teatro Bunraku, especialmente na utilização de elementos simbólicos e na abordagem e apresentação das cores, principalmente nos espaços, através da fotografia do filme.

\section{Primavera}

O ciclo da primavera coincide com todo o primeiro momento da história do casal Matsumoto e Sawako. Esse ciclo, apesar de construído em torno de apenas uma das três histórias, não deixa de se apresentar de forma bastante fragmentada, graças às construções de flashbacks e flash-forwards vistas até agora. Retomando a questão do flash-forward, quando a imagem do casal de "mendigos acorrentados" é apresentada, antecipando o que irá ocorrer com os dois, essa antecipação mantémse dentro do que poderia ser chamada de primeira estação, que é o momento da primavera. Isso fica claro pelas cores presentes na tela, tanto nos figurinos, em tons claros, como pela presença das cerejeiras e do tom rosado, que se expande até mesmo para o título do filme.

A primavera, então, vai ser marcada por um predomínio do branco e de tons pastéis. A estação no filme é marcada pelo rosa claro das flores das cerejeiras, que iniciam e encerram o ciclo, como já visto, pela mesma cena. Assim como no Bunraku o branco e as cores claras vão se apresentar como elementos simbólicos de representação da pureza e inocência, em Dolls, nesse ciclo inicial, a trama é marcada pela inocência de Sawako, abandonada por Matsumoto, mas também pela pureza dele, que abandona tudo para tentar resgatá-la. Evoca-se então uma sensação de esperança, de que Sawako possa se recuperar e o casal reencontrar o relacionamento rompido. A partir de alguns elementos simbólicos essa mesma esperança é tanto evocada, como vai sendo desfeita, no caminhar da estação. Esses elementos simbólicos aparecem ligados mais diretamente à figura de Sawako e, dentre eles, é possível destacar a borboleta, os anjos de porcelana e o brinquedo de soprar. 


\section{Sequência 5}
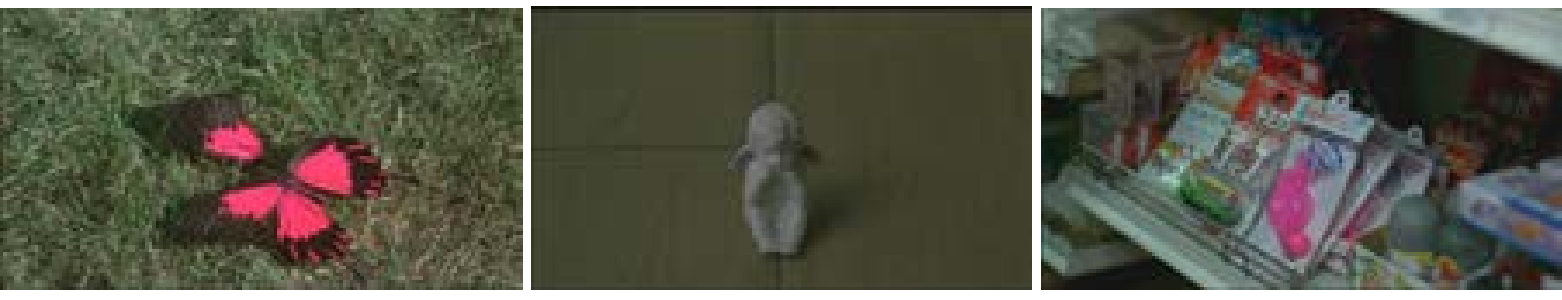

Os três objetos que perpassam o caminho de Sawako durante este ciclo. A borboleta, o anjo de porcelana e o brinquedo de assoprar. Destaque para as cores dos objetos, branco e rosa, que mantém a paleta de cores observada nesse ciclo da primavera.

Quando Matsumoto chega ao hospital, Sawako aparece sentada observando uma borboleta que, deitada na grama, apresenta uma de suas asas caída. A borboleta, símbolo de liberdade e transformação, é, no Japão, também símbolo da felicidade do matrimônio, representada pelo casal de borboletas masculina e feminina, Ocho e Mecho. Origamis destas borboletas são usados para decorar os gargalos das garrafas de saquê, durante cerimônias de casamento (Iverson; Lang; Yim, 2011). A borboleta reflete a quebra do relacionamento do casal. Quando Matsumoto se aproxima de Sawako, vemos a borboleta no primeiro plano da cena e apenas os pés do casal. A borboleta com sua asa quebrada reflete aqui a quebra do relacionamento dos dois, que levou Sawako à tentativa de suicídio, assim como o estado atual da garota, ferida e incapaz de se mover.

\section{Sequência 6}
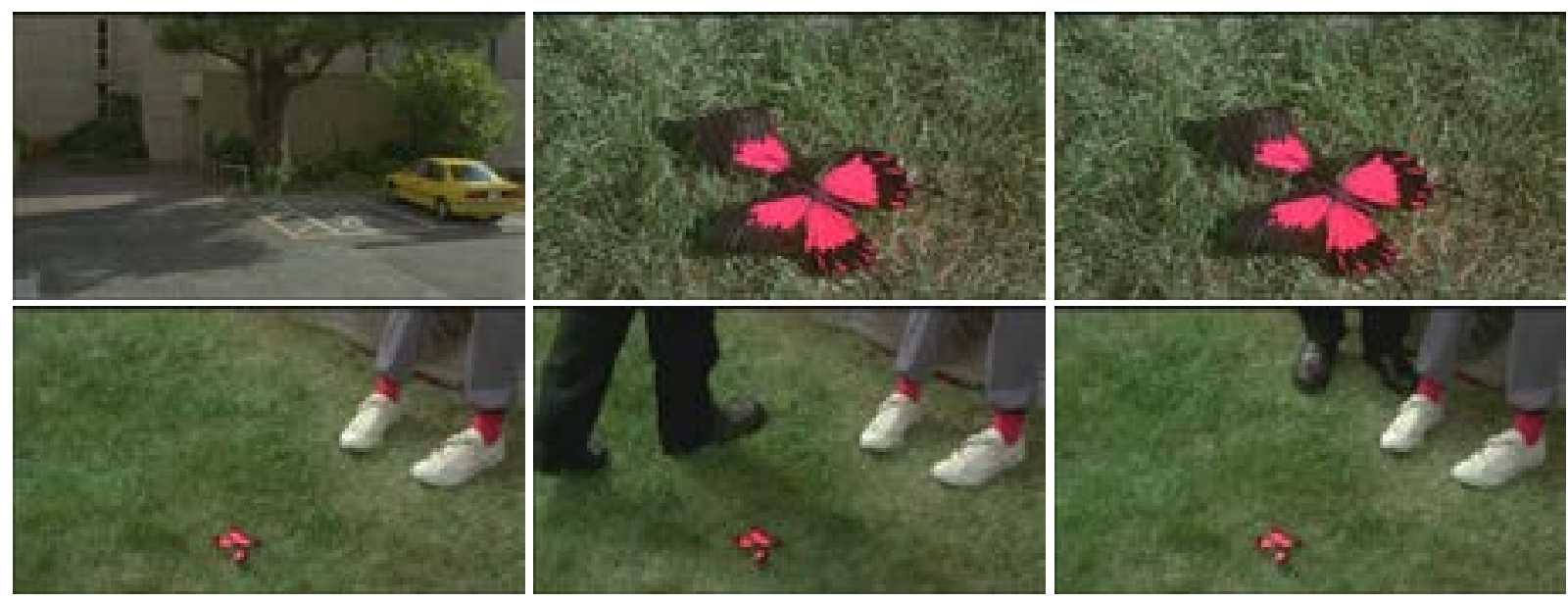

A chegada de Matsumoto no hospital, enquanto Sawako observa a borboleta. Em seguida o momento de aproximação dos dois, visto apenas da perspectiva da mesma borboleta.

O casal sai e a câmera foca a única asa deixada no chão, com a borboleta desaparecida, reforçando a conexão com a figura da jovem. Da mesma forma que Sawako sai do hospital junto à por Matsumoto, a borboleta também teria sido levada. Alimenta-se a expectativa de renascimento, de recuperação, pois mesmo que carregada este é o primeiro sinal de possível liberdade. Essa perspectiva se reforça quando Sawako, no quarto do hotel, observa os pequenos anjos de porcelana. Estes refletem 
sua inocência, assim como certa infantilidade vista em suas poses. Mais uma vez o símbolo está ligado à liberdade de voar, porém, assim como a borboleta não voava por não ter mais uma de suas asas, os anjinhos, ainda que inteiros, também só voam se carregados.

\section{Sequência 7}
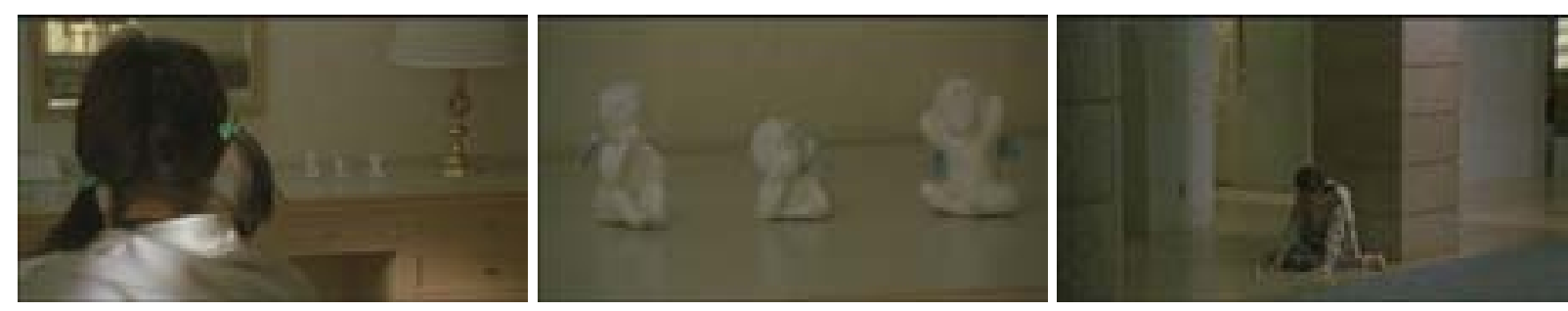

Sawako observando os anjos de porcelana e, posteriormente, conversando com um deles no salão do hotel.

A cena seguinte, porém, mostra Matsumoto saindo sozinho de carro e, ao acelerar, é visto que ele passa com a roda por cima da borboleta. O que ainda poderia restar daquele relacionamento, portanto, é atropelado pelo rapaz. A borboleta é esmagada por Matsumoto, da mesma forma como Sawako havia sido. Num momento seguinte, Sawako está no salão do hotel, buscando conversar com o pequeno anjo de porcelana. Quando Matsumoto assim como a esperança de liberdade de Sawako Mais uma vez é feita a conexão entre o estado de Sawako e a borboleta. Matsumoto leva-a de volta para o quarto. A mesma cena se repete no outro dia, quando ela resolve mexer nas flores da recepção. As atitudes de Matsumoto, continuamente resgatando Sawako, ao mesmo tempo que apresentam uma imagem de proteção, servem também para reforçar a noção de que a garota, assim como a borboleta e os anjos, não é capaz de voar sozinha, de que ela precisa ser carregada.

Em seguida, a relação de Sawako com o brinquedo de assoprar retoma os mesmos pontos. $O$ brinquedo representa a liberdade para o voo e, diferente dos momentos anteriores, dessa vez , quando Matsumoto tenta resgatá-la, ela acaba voltando e seguindo ininterruptamente com o brinquedo. Essa relação lúdica de liberdade que vai se estabelecendo, é completamente interrompida quando, após um assopro mais forte, a bolinha escapa e é amassada por um carro. Sawako se joga embaixo do veículo, tentando inutilmente salvar o brinquedo, mas a atitude é em vão e novamente se abate a quebra, a impossibilidade do voo, o rompimento da esperança que se formava. Ela é resgatada uma vez mais ao se colocar à frente de um caminhão, até que passa a ser amarrada ao carro por Matsumoto. Por fim, o anjo de porcelana é visto deixado no chão do carro, enquanto o casal sai, já como os mendigos amarrados, abandonando a esperança de renascimento e assumindo a caminhada, que encerra este ciclo. 


\section{Sequência 8}
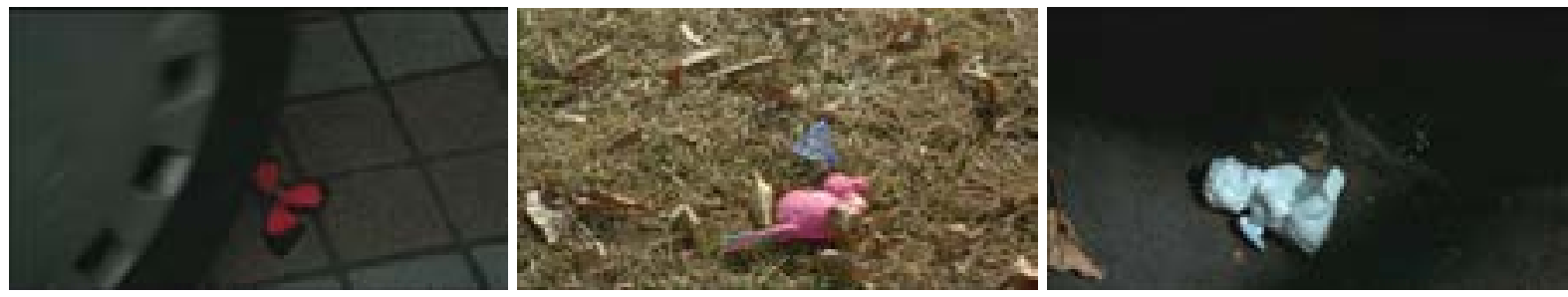

A borboleta atropelada por Matsumoto, o brinquedo quebrado que ficou pelo caminho e o anjinho de porcelana abandonado dentro do carro.

Os tons claros e a referência à pureza e inocência vão estar presentes em todo o decorrer dessa primavera, marcando visualmente esse momento. Outro fator importante é a antecipação, o flash-forward, que apresenta cuidadosamente para o espectador algo que ainda está para ocorrer, mas ainda sem o caráter de inevitabilidade, que vai ser construído ao longo das outras estações, especialmente no par outono/ inverno. Mantém-se aqui a possibilidade de outros acontecimentos, de reviravoltas, não somente para além do momento presente, como também para além dos flashforwards. Esses, portanto, vão sendo todos apresentados e confirmados dentro da mesma estação. A primavera, portanto, a partir desse recurso de adiantamento, começa e termina no mesmo ponto, na caminhada do casal. É o ciclo que apresenta o nascimento dessa caminhada, desse michiyuki, que o casal começa a percorrer e que vai inevitavelmente levá-los até a morte, até o inverno.

\section{Verão}

Um dos principais pontos deste ciclo é o estabelecimento das outras duas histórias. A própria passagem da primavera para o verão ocorre quando se encerra a cena do casal de "mendigos amarrados" e aparece imediatamente o chefe da máfia Hiro. Começa então esse novo ciclo, carregando um pouco da esperança primaveril, mas apresentando, pouco a pouco a irreversibilidade dos fatos.

No verão, as cores claras são substituídas por outras mais escuras, principalmente o verde e azul. Os tons fortes dessas cores, contrastando com os tons pastéis vistos antes reforçam a imersão nesse mundo do irreversível. A água e, mais especificamente, o movimento das águas, em contraste com o verde da floresta, desempenha papel fundamental neste ciclo. Constantemente podem ser vistos rios, trechos de mar e mesmo espaços com chuva que carregam os personagens por esse caminho, por essa correnteza dos rios e mares e pela imensidão da natureza.

O ciclo começa já com a segunda história. Hiro, já um idoso chefe da máfia, conversa com um rapaz que acaba de ingressar ao grupo. Em uma dessas conversas, o rapaz revela que abandonou sua mulher para que pudesse se dedicar a seu dever. Esta declaração faz com que o chefe retome seu próprio passado, quando ele abandonou Ryouko, exatamente para se dedicar aos deveres da máfia. Diferente da relação vista com Matsumoto e Sawako, apresentados como um casal que se desfaz e imediatamente busca se recuperar, a relação de Hiro e Ryouko já se apresenta traça- 
da. Boa parte da história do casal é, portanto, apresentada a partir do uso de flashba$c k$, reforçando a ideia de inevitabilidade que este ciclo carrega.

\section{Sequência 9}
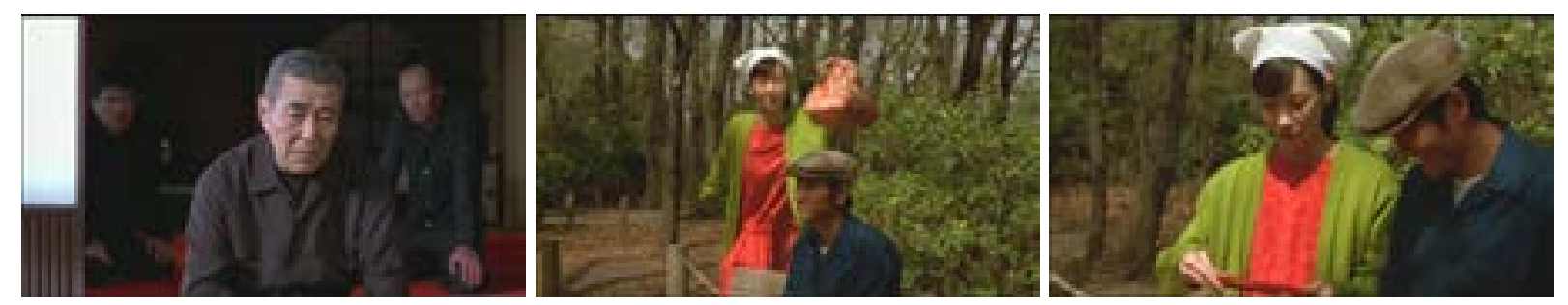

Hiro recorda dos momentos passados com Ryouko.

Uma questão a parte é a presença do personagem tetraplégico no decorrer desta história. Sua aparição, seguida de um flashback, cria o entendimento de que ele seria filho de um companheiro da máfia que Hiro tivera de manda matar. Há um reforço à noção do dever dentro desse grupo ao qual fazem parte. Por ser o responsável pela morte do pai, Hiro se prende a esse dever ao filho. Uma relação que se pauta diretamente na noção do giri. Hiro tem um giri para com ele.

Voltando ao casal, Hiro já abandonara Ryouko tantos anos atrás que não acredita que possa retomar esse relacionamento. Mesmo quando vai procurá-la, ele o faz pela retomada de uma lembrança, movido pela ideia de que já está velho e que teria pouco tempo de vida e não pela esperança de que ambos possam voltar a ficar juntos.

Quando ambos se reencontram, Ryouko ainda espera pelo namorado que conhecera, presa ao momento passado, incapaz de reconhecer. Aqui, assim como no Bunraku, figurinos e suas cores exercem papel fundamental no estabelecimento dessa relação, se apresentando como elementos de convenção e comunicação dos estados e características dos personagens. Hiro se difere do rapaz visto no passado de macacão e veste roupas sóbrias, com cores terrosas, e aparece em diversos momentos com um figurino marrom, cor que no teatro de bonecos evidencia os personagens idosos. Ryouko, por sua vez, aparece usando o mesmo vestido vermelho vivo com que aparece nos momentos de flashback, junto a um casaco e um lenço na cabeça, que ainda que mudem de cor, mantém o mesmo modelo, demonstrando que ainda vive no momento passado quando ela ainda era jovem.

\section{Sequência 10}
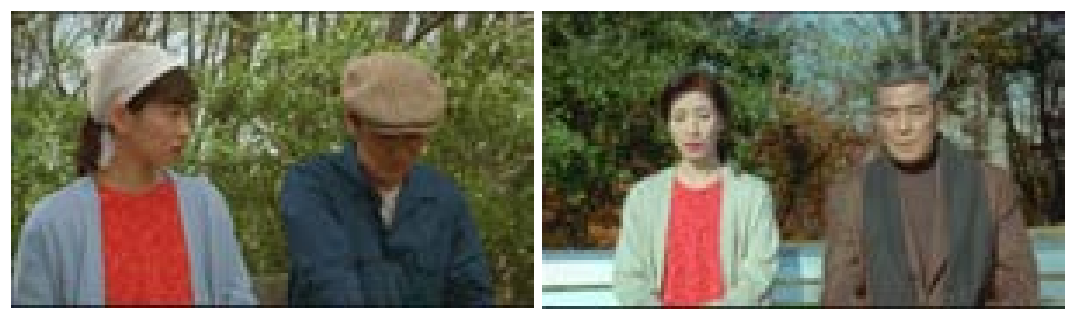

Ryouko e Hiro, respectivamente no passado e no presente. 
Seguindo a esse primeiro momento da história de Hiro e Ryouko retoma-se da caminhada do casal acorrentado. Nesse momento, destaca-se o sonho vivido por Sawako. Este sonho, ou pesadelo para ser preciso, apresenta alguns dos elementos e cores vistos na primavera, onde ainda representavam a esperança de liberdade, de um recomeço, sendo desfigurados, passando da esperança para a opressão. A lua, testemunha do momento de Sawako com o brinquedo de soprar, aqui encara o casal passando por essa parede de cata-ventos. O ar e o vôo que buscavam a liberdade antes, aqui aparecem nesses cata-ventos, presos, soprando o casal por essa caminhada. Eles passam por o que aparenta ser um festival de verão, reforçando a noção desse ciclo, onde os cata-ventos se transformam em uma sucessão de máscaras. Dessa sucessão surge a máscara de um bebê que se multiplica e toma o lugar de todas as outras, para, em seguida aparecer no rosto de um homem. É possível conectar essa máscara de bebê com a imagem dos pequenos anjos de porcelana. Em seguida esse homem aparece junto a outros dois. Três mascarados, assim como os três anjos de porcelana com os quais Sawako brincava no hotel. Ainda no sonho, estes homens arrastam e abusam a jovem, diante de um Matsumoto imóvel, que nada faz para impedir.

\section{Sequência 11}
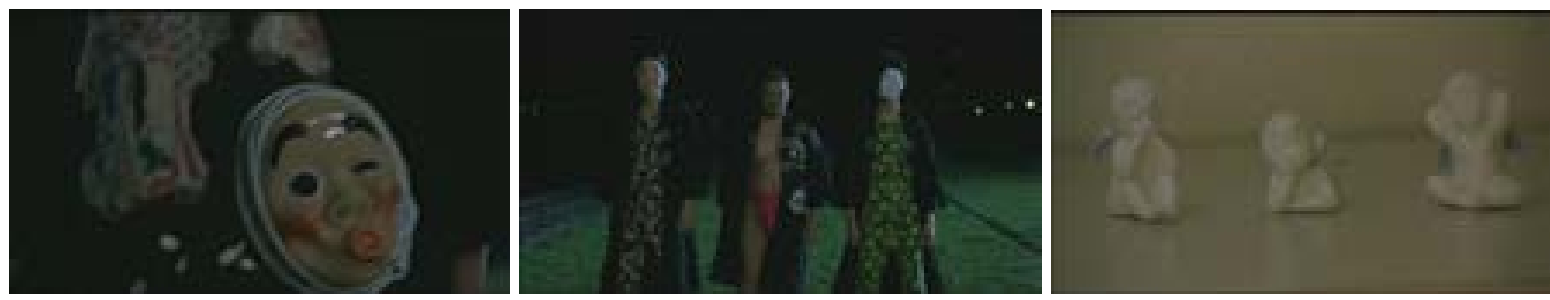

A máscara, em destaque, e os três homens, em comparação aos três anjos de porcelana.

Este sonho mostra Sawako encarando o abandono ao qual foi submetida, tendo de abandonar a infantilidade vista no ciclo da primavera, perdendo as esperanças alimentadas. A acordar, porém, Sawako vê que Matsumoto está cuidando dela, não apagando o que aconteceu, mas reforçando a ideia de que ele agora está lá. Não faz diferença aqui se nesse momento ela já é capaz de recordar tudo que aconteceu, mas o fato de que toma consciência de sua situação e, por isso mesmo, no momento seguinte, ao ver no chão a mesma máscara de bebê, ela, pela primeira vez, toma a frente da caminhada, puxando Matsumoto.

Um flashback apresenta a lembrança de uma brincadeira feita por Sawako, na praia, amarrando a perna de um adormecido Matsumoto numa prancha. Ela joga seu chapéu ao longe e pede ao rapaz para buscá-lo. Sem perceber que estava preso, ele cai, para o divertimento da garota. Essa lembrança contrasta com a imagem do casal em seu estado atual, que olha o mar diante um precipício. Um chapéu, assim como o que motivou a brincadeira lembrada, passa voando pelos dois, escapando como escapou aquela relação, reforçando a noção de que aquele passado já não pode mais ser retomado.

Uma característica importante desse ciclo é o fato de Matsumoto e Sawako deixarem de se comunicar verbalmente, de se falarem, após o início de sua caminhada. É 
a partir desse momento que o casal passa efetivamente a ser visto como os mendigos acorrentados e, assim como no Bunraku o corpo e a voz dos bonecos se apresentam em planos distintos. Em Dolls, quando o casal passa a se identificar como marionetes humanas, suas falas desaparecem e o diálogo do filme é deslocado para as outras duas histórias que surgem.

A terceira história se inicia lançando mão, novamente, do uso de um adiantamento, de um flash-forward, como discutido antes, porém, dessa vez, se entrecruzando com a caminhada de Matsumoto e Sawako. Nukui aparece já cego, sendo guiado por uma mata pela tia de Haruna. Em seguida, o casal de mendigos acorrentados caminha por uma praia, com a mata ao fundo, e nesse caminho é ultrapassado pelo cego e sua guia na mesma praia. A sequência se encerra com Haruna, sentada em algum lugar dessa praia, com parte do rosto coberto. Na cena seguinte, a mesma Haruna é vista novamente, agora porém, cantando e com o rosto completamente à mostra, apresentando sua imagem de ídolo pop.

\section{Sequência 12}
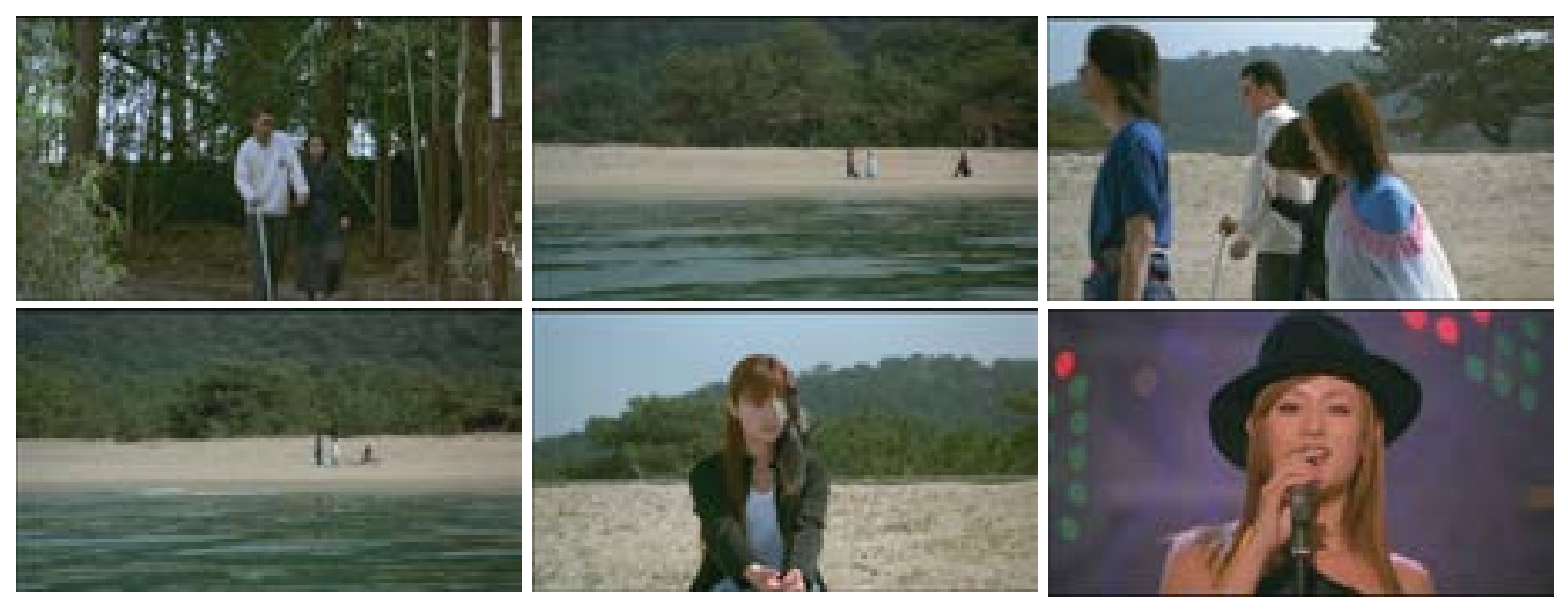

Sequência de passagem e apresentação dos personagens da terceira história. Destaque para o plano lateral aberto, que dialoga com o ponto de vista do espectador do teatro Bunraku.

Assim como a relação de Hiro e Ryouko, a relação de Nukui com a cantora Haruna também será pautada pela devoção, mas, enquanto a primeira apresentava a devoção da mulher ao homem que amou no passado, esta mostra a relação do rapaz com a cantora que idolatra. Justamente por ser uma relação pautada pela idolatria, Nukui só consegue se aproximar dela mediado pelo aparato midiático, ao segui-la, ao buscar autógrafo, adorar suas imagens, pôsteres, estabelecendo uma disputa, com outro fã, esse papel de fidelidade e adoração à cantora.

A fragilidade desse ídolo é colocada à prova quando Haruna se acidenta. As marcas no rosto atingem a cantora exatamente naquilo que a identificava, na sua imagem. Como um boneco quebrado, incapaz de ser emendado, Haruna é descarta$\mathrm{da}$, abandonada, se isolando completamente para que ninguém testemunhe suas feridas. Nukui se vê impedido de se aproximar exatamente porque sua idolatria é encarada como uma adoração à imagem da cantora, esta imagem que já não mais existe. Nesse momento, a disputa com o outro fã ganha força novamente, impulsionando o 
rapaz a buscar uma solução para que seja ele a se aproximar da cantora novamente. A solução encontrada por ele é se cegar, porém, antes de furar os próprios olhos, ele encara ininterruptamente a imagem de Haruna, reforçando a relação de adoração àquela imagem midiática. Quando questionado pela cantora sobre seus olhos, Nukui responde que achou melhor não enxergar mais. A única forma de chegar perto dela, portanto, é não ser capaz de enxergar suas feridas, é vê-la para sempre como a imagem que idolatrava.

A sequência seguinte mostra um entrecruzamento das três histórias, acompanhadas pela trilha sonora. Se o decorrer do filme em si já se propõe como uma caminhada, este momento é um que se destaca como um diálogo direto com a cena do michiyuki, cena de caminhada do Bunraku. A construção dessa caminhada se dá a partir da combinação do narrador, que apresenta poeticamente os lugares percorridos, assim como os sentimentos das personagens, da música que ambienta e define o andamento desses acontecimentos, e dos personagens, que se colocam em ação dentro desse ambiente estabelecido. Nesse momento do filme, vê-se a conjunção dos casais das três histórias, dentro desse cenário construído aqui pela fotografia e pela edição, tomando o lugar desse narrador, junto à trilha sonora, que se destaca ao estabelecer não apenas o ritmo, mas toda a dinâmica dessa caminhada, combinando som e imagem, assim como se combinam narrador e músico no Bunraku.

Mesmo a noção de desfecho, implícita ao michiyuki, que no teatro de bonecos encaminha a trama para seu final, pode ser entendida aqui de forma condensada. Apesar desse momento em Dolls não levar ao desfecho completo do filme, ele leva ao final desse ciclo do verão e, com o início do outono, ao desfecho da segunda e terceira histórias. Haruna caminha com Nukui por entre um jardim de flores, enquanto Ryouko finalmente abandona o namorado passado e aceita a presença de Hiro a seu lado. Estas atitudes, aparentemente simples, encaminham os casais para sua derrocada.

O verão, portanto, com a correnteza de suas águas, arrasta os casais. Matsumoto carrega Sawako cada vez mais para um caminho que os engole. Hiro ignora seus deveres e se lança em busca de um amor que ficou no passado. Já Nukui, na atitude mais impulsiva, cega os próprios olhos para poder se aproximar da cantora que idolatra. O ciclo se encerra com essa versão condensada do michiyuki, que se não leva diretamente ao fim, leva ao início desse fim, com a chegada do outono.

\section{Outono}

O outono se inicia com a caminhada de Matsumoto e Sawako em meio a um terreno coberto pelas folhas avermelhadas que caem das cerejeiras. Em todo o ciclo observa-se a predominância do vermelho, em meio a tons escuros. $O$ azul da água e o verde da floresta ainda aparecem, mas agora em tons muito mais fechados. A noite aparece com pouca iluminação e ressaltando as sombras. O vermelho, que na simbologia do teatro Bunraku representa a força da vida, vai aparecer como metáfora do fim dessa vida, com a queda dessas folhas vermelhas, que passam a cobrir o caminho dos "mendigos acorrentados".

Ciclo mais curto, o outono vai apresentar o desfecho das duas histórias que se 
iniciaram no verão. As atitudes impulsivas de antes, levam Hiro diretamente à morte tanto o fã Nukui, como também o chefe da máfia Hiro. Junto à cena do casal caminhando sobre folhas caídas, Nukui aparece andando por uma estrada, aparentemente voltando de seu encontro, tocando em sua gaita a música de Haruna. Volta-se para Sawako e Matsumoto, que caminham pela noite, até encontrarem um abrigo. Ela observa uma folha caída sobre os ombros do adormecido Matsumoto. Nesse exato momento, aparece a imagem de Nukui morto, aparentemente por um atropelamento, em meio a uma poça de sangue. A sequência inteira apresenta então uma conexão direta entre as duas histórias, usando a queda da folha de cerejeira como metáfora para essa morte.

Retoma-se aqui a relação entre o giri e o ninjô. O fã Nukui, ao cegar os próprios olhos, segue uma vontade individual. Ele renega seus deveres perante a sociedade, perante seu emprego, para poder satisfazer o desejo de estar próximo à cantora Haruna. Por caminhar cego é que Nukui acaba atropelado e seu ato impulsivo é justamente o que o leva à morte.

\section{Sequência 13}
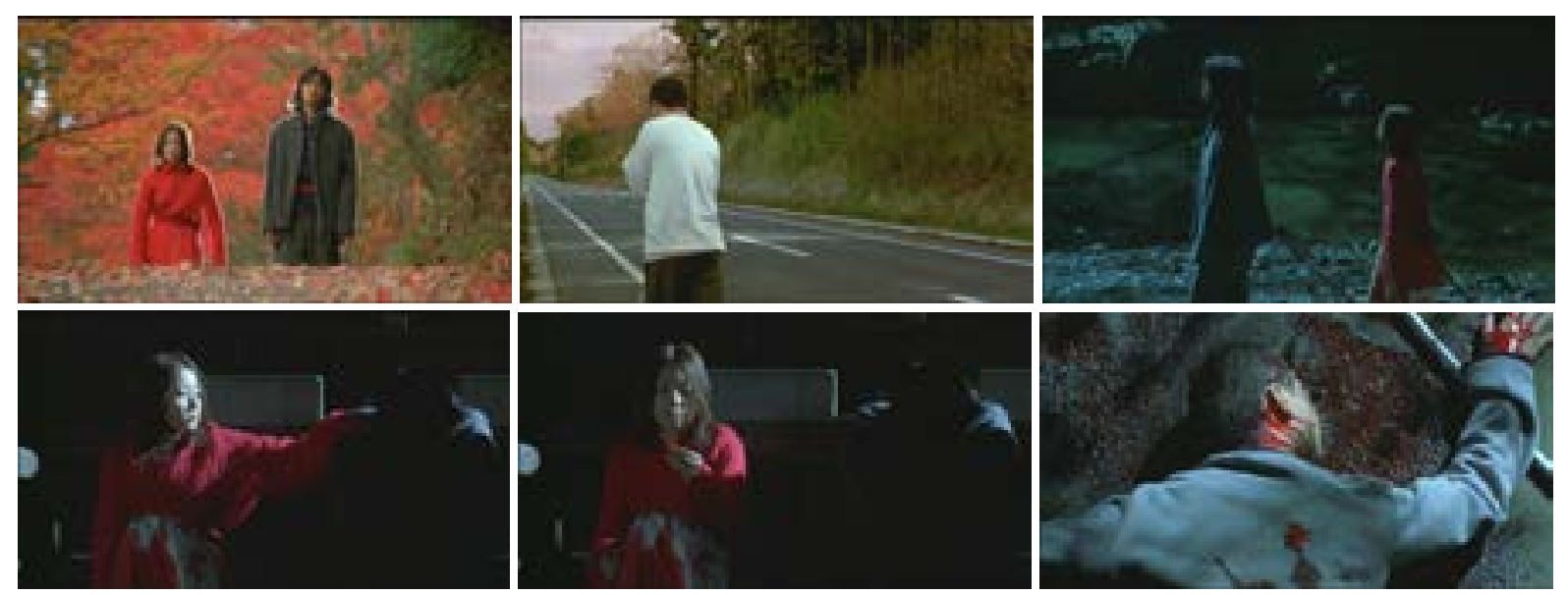

Sequência inicial do outono, mostrando a morte de Nukui. Destaque para a conexão entre a morte e a queda da folha de cerejeira, segurada por Sawako.

O mesmo ocorre com a segunda história. Imediatamente após a sequência que mostra a morte de Nukui, Hiro aparece retornando de seu encontro com Ryouko. $O$ chefe caminha sozinho, enquanto seus seguranças aguardam. Ele é seguido de perto por um homem que, no meio do caminho, saca uma arma e aponta em sua direção. Hiro vira-se a tempo de ver seu assassino e, imediatamente, a imagem de uma folha de cerejeira caindo sobre um rio aparece na tela. $O$ jovem Hiro havia abandonado Ryouko para poder dedicar-se ao seu grupo, à máfia. Quando decide procurá-la, Hiro abandona esse dever. Levado pelo seu sentimento, ele abre mão de sua proteção, se expondo às circunstâncias que geram seu assassinato. 


\section{Sequência 14}
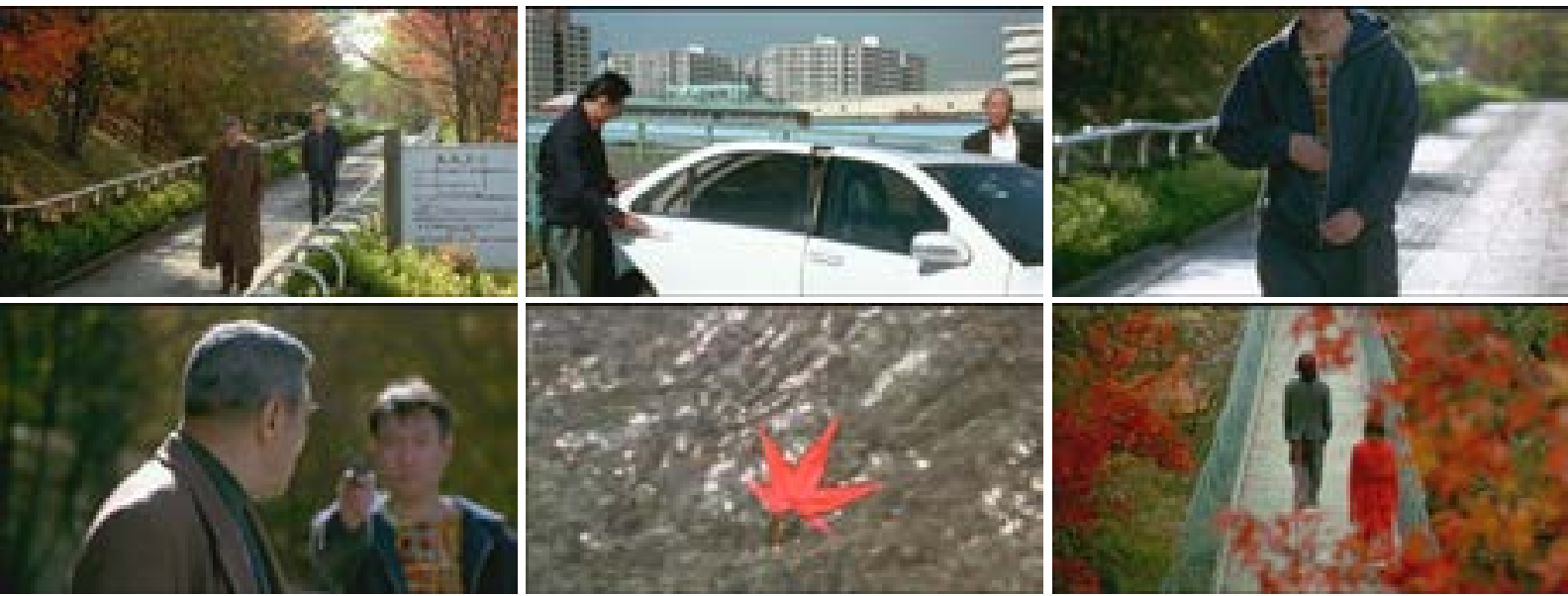

Sequência da morte de Hiro. Assim como na sequência anterior, destaque para a conexão entre a morte e a queda da folha de cerejeira.

Assim como no teatro Bunraku, ao renegar o giri, ao não cumprir seus deveres, cedendo completamente ao individualismo, ao ninjo, o personagem acaba por torna-se vítima de suas atitudes, desencadeando uma sucessão de acontecimentos que o levam a uma situação da qual não tem como escapar.

Este ciclo é também marcado pelo silêncio, que já preponderava na primeira história, mas que agora ecoa por todo o filme. No artigo The Aesthetics of Silence in Cinema, Divya Kumar (2012) discute a abordagem cinematográfica do silêncio, dentro da lógica do cinema falado, comparando-a, em determinado momento, com a noção da elipse, recurso estilístico onde se omitem da frase uma ou mais palavras, subentendidas pelo contexto, no sentido de colocar o silêncio como elemento de construção estética e dramática.

[O] silêncio mantém uma presença, assim como se refere à fisicalidade da ausência [...] Momentos de silêncio podem ser usados como método de (des) figuração, (de) narrativização, e (des) articulação. Como símbolo, o silêncio funciona como lei ou linguagem e como associação de ideias ou retóricas. O silêncio pode ser visto como um conjunto de regras organizadas de forma semelhante à linguagem (Kumar, 2012, p. 736). ${ }^{8}$

Em Dolls o silêncio aparece como construção dramática, no processo de desumanização dos personagens, de objetificação, de transformação destes em marionetes humanas, em bonecos que deixam de ter voz. Pensando a partir dos termos mencionados no artigo, o silêncio em Dolls age como método de figuração e narrativização, dentro da diegese do filme, mas ao mesmo tempo age como metáfora da desarticulação desses personagens, que perdem a capacidade de se comunicarem. O casal Matsumoto e Sawako perde-se cada vez mais em seu caminho errante. Enquanto isso, Haruna e Ryouko esperam por seus companheiros que nunca irão

\footnotetext{
${ }^{8}$ Silence maintains a presence as well as refers to the physicality of absence (...) Silent moments can be used as a method for (dis) figuration, (de) narrativization, and (dis) articulation. As a symbol, silence functions as law or language and association of ideas or rhetoric. Silence can be seen as a body of rules organized in ways similar to language. (Kumar, 2012, p. 736).
} 
retornar. As duas velam as mortes dos dois homens, inconscientes de sua situação. Manipuladas por um destino, como bonecos que não conhecem os caminhos para onde serão levados.

Conclui-se então que o outono apresenta o começo do fim de uma caminhada; como a queda das folhas vermelhas da cerejeira que carrega as mortes de Hiro e Nukui. Esses acontecimentos apontam para o desfecho do casal de mendigos acorrentados, com a constatação da inevitabilidade dessa morte que se aproxima cada vez mais de Matsumoto e Sawako.

Uma questão importante a ser destacada é o fato de apenas a primeira história percorrer completamente toda a passagem das estações do ano. Nos casos de Hiro e Ryoku e Haruna e Nukui, vê-se um andamento mais condensado, praticamente limitado à ideia de verão e outono. Como se a intenção fosse de que essas histórias já começassem com a intensidade do verão e não chegassem à extrema derrocada do inverno, mas que abrissem caminho para o desastre. É após a morte de Hiro e de Nukui, ambas expressas pelo vermelho intenso e pela queda das folhas de cerejeira, que os mendigos acorrentados entram no mundo branco e frio da neve, nesse inverno que consome todas as esperanças.

\section{Inverno}

Na passagem do outono para o inverno, a corda vermelha dos "mendigos acorrentados" arrasta para a neve as folhas caídas das cerejeiras. A queda das folhas, como visto anteriormente, se apresentam como metáfora para a morte de Nukui e Hiro. Pode-se dizer então que o casal carrega a morte pelo seu caminho, espalhando as folhas vermelhas pelo branco da neve.

A ligação com o outono aparece também no momento seguinte, quando Sawako e Matsumoto estão sentados no túnel, com quase nenhuma iluminação e, por um instante, toda a cena se enche com o vermelho da lanterna traseira de um carro em movimento. Conectado às mortes, o vermelho adianta também o desfecho do casal, banhados por essa cor que marcou as mortes de Nukui e Hiro. Essa morte é reforçada pela completa escuridão que se segue. Com a chegada do inverno, a caminhada de Matsumoto e Sawako, iniciada em meio às cores claras da primavera, encontra o branco da neve. Esse branco, porém, contrasta com o preto da noite. Preto que no Bunraku carrega exatamente o significado da morte. Já de início, portanto, todos os elementos apontam para esse desfecho inevitável ao casal. As próprias vestimentas reforçam essa relação, com Matsumoto vestindo cinza escuro e Sawako de vermelho, coberta com um sobretudo preto.

O ciclo também é marcado pela retomada dos flashbacks, comparando o momento do casal com um inverno passado. Um primeiro flashback no inverno mostra o casal em um momento feliz, brincando e fazendo poses para um amigo que os filma. A presença dessa terceira pessoa é importante não apenas por revelar que Matsumoto e Sawako pretendiam se casar, mas principalmente porque reforça a marginalização enfrentada pelo casal. Não apenas eles não são mais capazes de retomar ao relacionamento entre si, mas também não se relacionam com outros, e continuam vagando como párias. 


\section{Sequência 15}
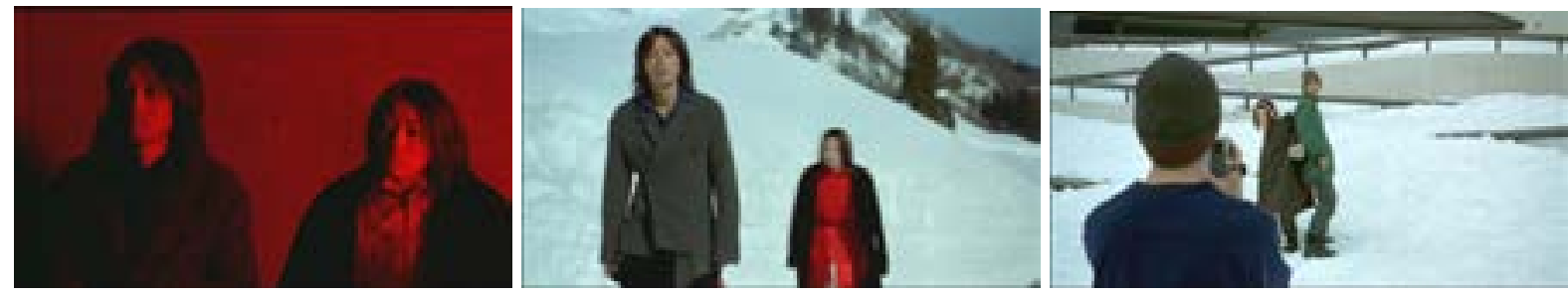

Da esquerda para a direita, o casal banhado pela luz vermelha, as vestimentas com as quais eles iniciam o caminho e o flashback de um inverno passado.

Continuando a caminhada, o casal se depara com um varal vazio, em que aparecem pendurados os bonecos de Chubei e Umegawa, mas aqui com o tamanho de humanos. Estes desaparecem, mas em seu lugar ficam suas vestes, que vão ser tomadas pelo casal. Matsumoto e Sawako tomam por completo o lugar das marionetes, vestindo suas vestes para essa etapa final do caminho. A relação das cores do figurino, de certa forma, se mantém, com Sawako primordialmente de vermelho e Matsumoto de cinza escuro.

\section{Sequência 16}
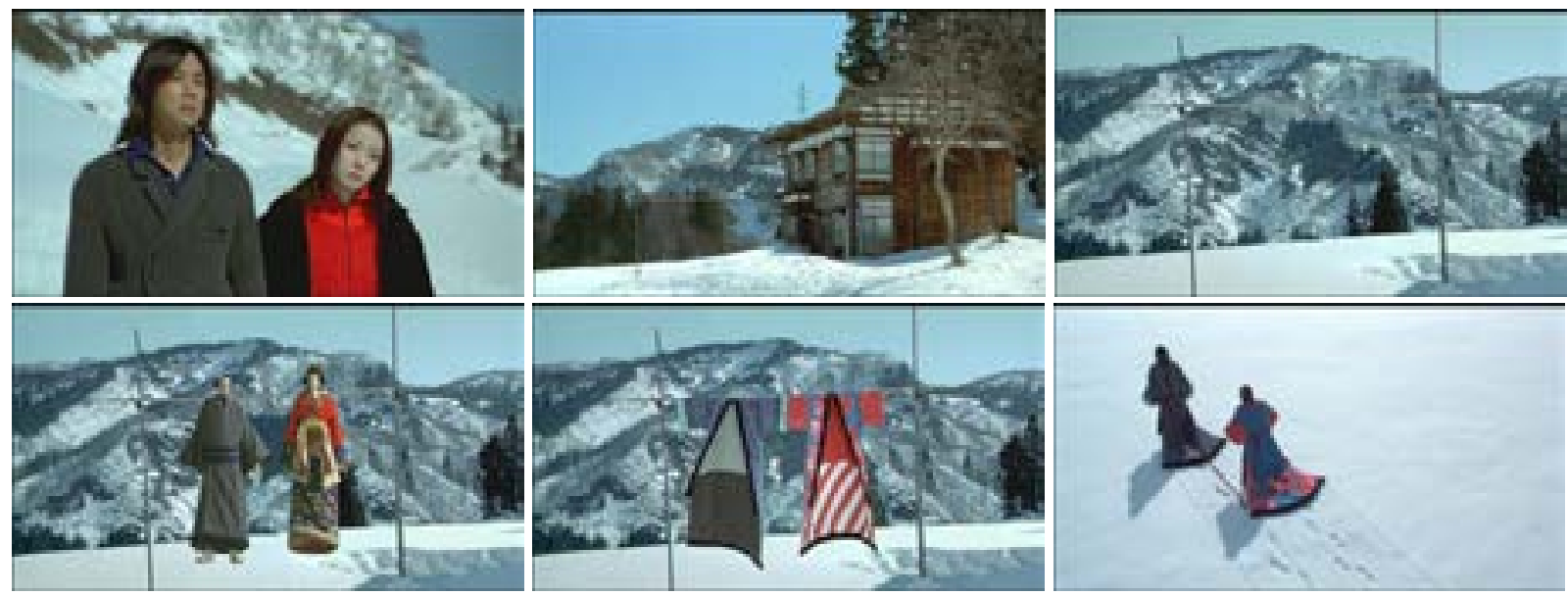

Sequência em que as vestes do Bunraku aparecem no varal.

Com o casal já vestindo as roupas dos personagens do Bunraku, a sequência da cena apresenta a relação com um espaço que pode ser considerado altamente teatralizado. Surge a imagem de um caminho em relevo, em pequeno aclive, num trecho deserto de estrada, coberto de neve. A sequência ocorre à noite e a subida só possui um ponto iluminado, em torno de um poste, onde podem ser vistas duas árvores, completamente sem folhas, assim como a neve que segue caindo. A câmera permanece completamente parada e, aos poucos, Matsumoto e Sawako aparecem em cena, ainda que muito mal iluminados, subindo a estrada.

Assim como a neve, as cores dos figurinos só conseguem ser detectadas quando o casal passa próximo ao poste. Esse facho de luz é bastante significativo para a 
noção e construção teatral da cena, já que, observando bem, é possível perceber que essa luz não vem diretamente do poste, como a princípio pode aparentar. A neve não só é iluminada acima desse poste, como deixa transparecer que a luz incide num ângulo diagonal, como se fosse projetada por um refletor, como em um palco. Durante todo o tempo não há nenhum tipo de aproximação ou movimento da câmera. O casal segue até o final desse "cenário", e só quando chegam ao fim, quando eles teriam saído para a coxia do "palco", segue um novo ângulo de filmagem com o decorrer da caminhada.

\section{Sequência 17}
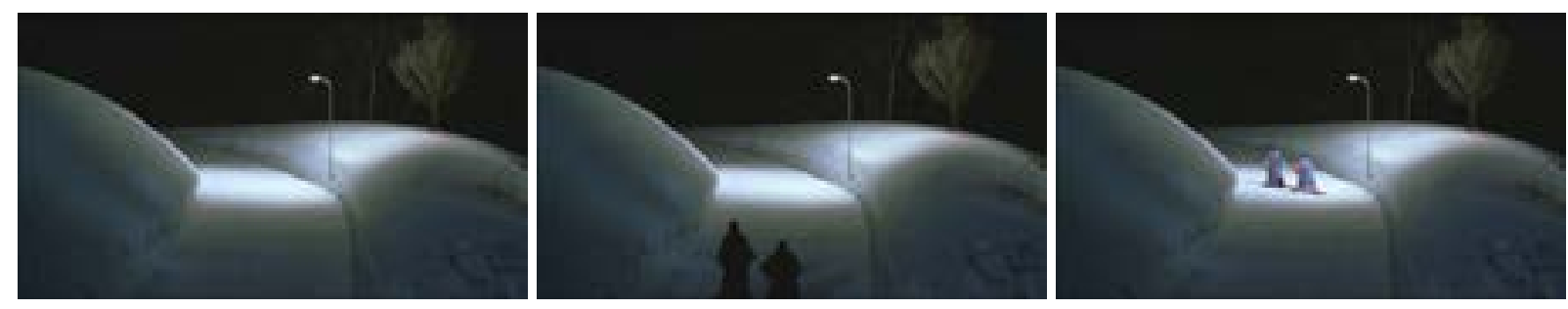

A caminhada do casal por esse "cenário" na neve.

Outro flashback surge quando o casal interrompe sua caminhada em frente a um restaurante. Em uma reunião de amigos, o noivado de Matsumoto e Sawako é anunciado. Alegando não ter tido dinheiro suficiente, o rapaz, ao invés de uma aliança, dá a ela um cordão com um pingente na forma de um anjo. Com o fim do flashback, a felicidade do casal contrasta com a imagem do rosto de Matsumoto. Ele é tocado por Sawako, que está a suas costas, e virando-se para ela, a vê segurando o mesmo pingente. O rosto dela esboça um sorriso, que logo se transforma em uma expressão de choro. Chegando próximo ao final de seu caminho, os dois se abraçam, mais uma vez como um casal.

Dando continuidade ao que havia sido visto com o pesadelo de Sawako no verão, os flashbacks vão apresentar toda a retomada de sua consciência e de sua memória. Se anteriormente, presenciou-se uma primeira conscientização de seu estado, agora ela aparece consciente de todos os acontecimentos, principalmente da quebra do compromisso de noivado e do abandono ao qual foi submetida. O pingente surge como a única conexão restante entre esse casal do passado com os atuais mendigos acorrentados. Ainda que essa conexão chegue a criar uma sensação de resgate, de retomada desse relacionamento que havia ficado esquecido, tudo é quase que imediatamente rompido, quando em seguida, enquanto o casal descansa diante de uma fogueira, eles são expulsos por um funcionário do restaurante. Já em primeiro plano, essa expulsão retoma a questão da marginalização dos dois, mas um fator importante aqui é que a voz desse homem é a única a quebrar o silêncio que domina todo esse inverno. Essa voz age empurrando-os de volta a seu caminho. O homem praticamente não aparece enquanto fala (só um pedaço mínimo de seu braço direito é visto nesse momento), só entrando em cena depois de o casal ter partido. É uma voz que vem de fora, que os direciona, que os retorna à condição de marionetes. Não atoa, o momento seguinte mostra já uma ligação direta com os bonecos do Bunraku. 
O casal corre pela neve. O ângulo mais uma vez ressalta a movimentação horizontal. A câmera se aproxima e aparece a imagem de Chubei e Umegawa no teatro Bunraku, repetindo um momento da tentativa de fuga do casal de bonecos. A sequência se repete, ao retornar para Matsumoto e Sawako, com a câmera se aproximando ainda mais e cortando uma segunda vez para o casal do Bunraku, com os "mendigos acorrentados" retornando em definitivo.

\section{Sequência 18}
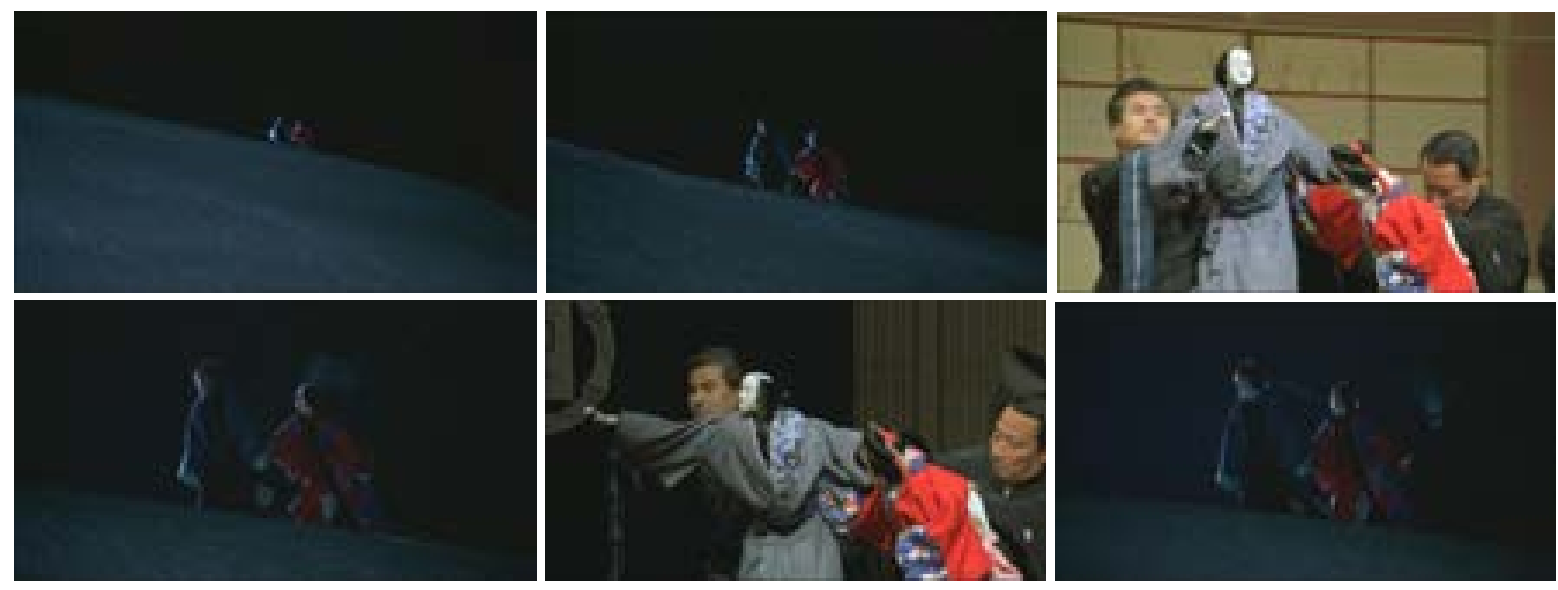

A sequência da corrida, ligando a imagem do casal de humanos, Matsumoto e Sawako, à cena inicial dos bonecos Chubei e Umegawa.

Assim como os bonecos, o casal de humanos, transformados em marionetes, tenta fugir de seu destino, mas, assim como na história de Meido no Hikyaku, não existe escapatória para Matsumoto e Sawako que escorregam na neve e caem rapidamente. Após essa queda, a tela escurece completamente por uma fração de segundos, até mostrar o casal em meio a um precipício, preso em um galho seco, apenas pela corda que os amarra. Ao se focarem os rostos dos dois, percebe-se que eles ainda estão vivos. Isso, porém, é o que menos importa, pois, ainda que aquele último fio de vida, representado pela corda vermelha, os sustente, o fim dessa vida é inevitável. As únicas alternativas que lhes restam são cair do precipício, ou permanecerem lá, pendurados indefinidamente, a espera de suas mortes.

\section{Sequência 19}
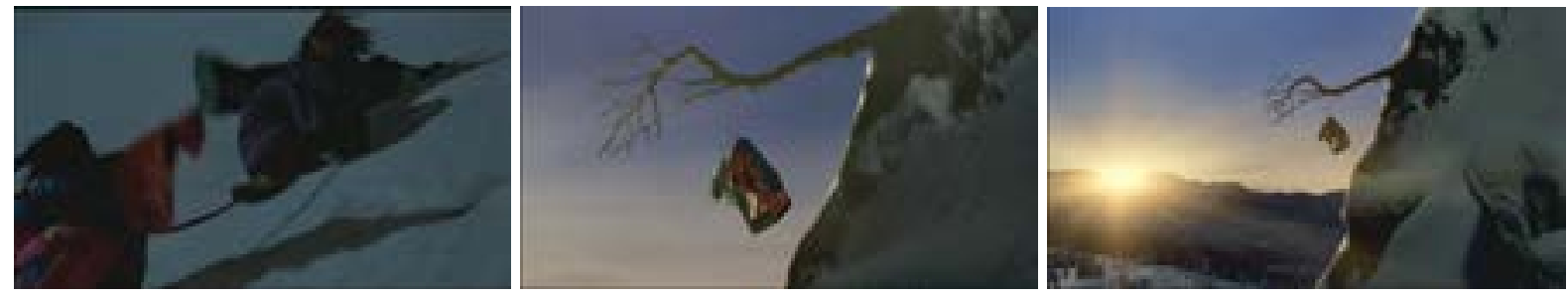

A queda de Matsumoto e Sawako para o precipício

A caminhada que se iniciou na primavera encontra seu fim no inverno. A brancura da neve varre a tela, mas o que começa durante o dia, segue para a noite, tor- 
nando a imagem cada vez mais negra com a aproximação do desfecho da trama e da inevitabilidade da morte. O inverno de Matsumoto e Sawako se encerra com os dois pendurados, ao amanhecer de um novo dia, como dois bonecos, duas marionetes guardadas pendurados ao fim de um espetáculo.

\section{De humanos a bonecos}

Com o fim do inverno, no momento final do filme, retoma-se a relação apresentada inicialmente no filme com os bonecos do teatro Bunraku. Chubei e Umegawa aparecem novamente e o processo se repete, eles se olham e voltam a olhar para aquela história que se encerrou, reafirmando a posição de contadores e mediadores daquela história. Eles olham uma última vez para a cena, depois se olham e viram novamente na direção da câmera, não olhando diretamente, mas para além dela. Aquelas histórias desfilaram diante deles e através deles que foram contadas. $O$ espectador do filme, portanto, assistiu às três histórias pelo olhar de Chubei e Umegawa.

\section{Sequência 20}
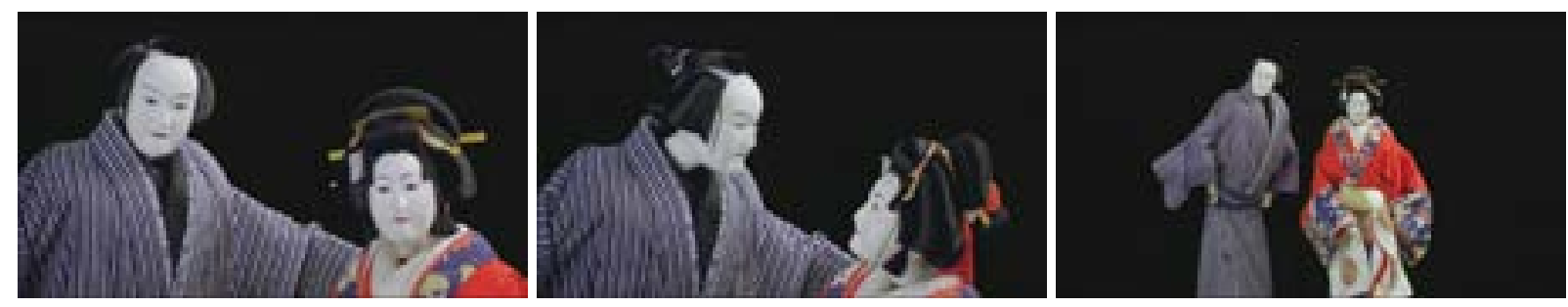

Chubei e Umegawa no momento final do filme

Dolls vai apresentar não um teatro filmado, mas um conjunto de imagens que dialoga com os elementos presentes na encenação do teatro Bunraku, como o uso das cores, da música e até mesmo a interpretação dos atores, referenciados dentro da construção cinematográfica e da sua narrativa. Muitas dessas questões, levantadas ao longo do texto, não são novidades, mesmo nos filmes do próprio Kitano, mas ganham todo um novo contexto em Dolls, como apontado por Cassio Abe:

É claro, as narrativas dos filmes de Takeshi Kitano foram sempre permeadas pela simplicidade do "todos só morrem" e "nada muda". No entanto, a totalidade neles é composta na movimentação de seus detalhes, que avançam, como dardos, dando-lhes uma complexa luminescência. No caso de Dolls, a movimentação desses detalhes possui uma qualidade mecanicista não vista antes e isso aumenta a sensação alegórica do filme (Abe, 2005, p. 260 - tradução Gustavo Henrique). ${ }^{9}$

Essa diferença se dá exatamente pelo diálogo do filme com o teatro Bunraku, que não se apresenta de forma limitada, como simples referência. A própria qualidade mecanicista destacada por Abe pela forma como se impõe aos personagens toda

\footnotetext{
${ }^{9}$ Of course, the narratives of Takeshi Kitano's films have Always been permeated by the simplicity of "everyone only dies" and "nothing changes." However, their totality is composed of the darting motions of their details, giving them a complex luminescence. In the case of Dolls, the movement of these details has a mechanistic quality not seen before, and this heightens the film's allegorical feel. (Abe, 2005, p. 260).
} 
essa transformação em marionetes humanas, em bonecos que desfilam por esse caminho que não controlam. Um caminho que os leva de forma precisa e inevitável até suas mortes. A morte em Dolls se diferencia justamente porque vem através da precisão desse caminho, que é o próprio caminho do michiyuki, do teatro Bunraku.

\section{Referências}

ABE, Casio. Beat Takeshi vs. Takeshi Kitano. Trans. William O. Gardner and Takeo Hori. New York: Kaya Press, 2005.

COSTA, Maria Helena Braga e Vaz da. Cores \& filmes: um estudo da cor no cinema. Curitiba: CRV, 2011.

IVERSON, Patsy Wang; LANG, Robert J.; YIM, Mark. Origami 5: Fifth International Meeting of Origami Science, Mathematics, and Education. Flórida: CRC Press, 2011.

KITANO, Takeshi. "Production Note". In: Dolls - official web site, 2002. Disponível em: http://www.office-Kitano.co.jp/dolls/en/pronote.html Acesso: 16 out. 2011.

KITANO, Takeshi. Disponível em: http://www.kitanotakeshi.com Acesso: 26 set. 2010.

KITANO, Takeshi. Boy. Vertical, 2007

KUMAR, Divya. "The Aesthetics of Silence in Cinema". In: Avanca|Cinema 2012 (p. 763-744). Avanca: Edições Cine-Clube de Avanca, 2012.

Recebido em: 07/06/2015

Aprovado em: 29/02/2016 